\title{
The future of the teaching profession from the perspective of students with a Major in Education
}

\author{
Jensy Campos Céspedes ${ }^{1 *}$, Walter Solano Gutiérrez ${ }^{2}$ \\ 'Education Research Center, State Distance University, Costa Rica \{ycampos@uned.ac.cr\} \\ 2Didactics and Curriculum Chair, State Distance University, Costa Rica \{wsolano@uned.ac.cr\} \\ Received on 15 June 2016; revised on 4 October 2016; accepted on 21 March 2017; published on 15 July 2017
}

\begin{abstract}
The article offers the results obtained in a study where, through the application of a survey and the development of a discussion forum with students from education majors, information about their perceptions with regard to four axes related to the future of the teaching profession was obtained, as follows: the teacher profile, the student characteristics, the participation of the family and the community in the education process and the curricular changes. From the study, it can be observed that the family and the community are perceived as the organizations with greater trends towards change as a consequence of the technological development and the globalization processes of societies, whilst the teacher profile, the concept of student, of school and curricula, tend to remain within the status quo. The perceptions shown by the future teachers who participated in the study demand relevant changes in the training processes of the education professionals.
\end{abstract}

KEYWORDS: TEACHER COMPETENCES, PROSPECTIVE, PERCEPTION, TEACHING, EDUCATION, STUDENT-PROFESSOR

\section{INTRODUCTION}

The capacity of developing historical awareness and of anticipating the future are, conditions typical of human nature. Freymann (2011) states that the anticipating capability is the one that influences more on the survival of people since "imagining the course of events, inventing alternatives, calculating risks, finally, rehearsing possible solutions allows that, in case of failure, what dies are the hypotheses and not their inventors" (p. 318).

The education field has not been exempt of works geared towards imagining the future, on the contrary, there is a multiplicity of studies oriented towards inquiring about the future of education (Baofu, 2011; Forssell, 2015; Hargreaves \& Lo, 2000; MacBeath, 2012; Pavlyuk \& Ivanchyuk, 2016; Sikula, 1989). The Organization of Cooperation and Economic Development (OCED), for example, has been performing studies for over a decade and more, to build possible future education scenarios with the purpose of making a deeper analysis and identifying the changes that should be made today in the education field (Oficina Internacional de Educación, 2004; OCDE, 2010). For the OCED, the future education

\footnotetext{
*To whom correspondence should be addressed:

474-2050

Mercedes de Montes de Oca

San José, Costa Rica
}

scenarios behave within two probable stadiums: the status quo or change. The great majority of the research relating to building future education scenarios has been performed based on the reflection or point of view of the in-service teachers and the decision makers in the education systems of countries ascribed to the UNESCO. In the case that concerns us, the study was performed not with the teachers' opinion but rather with that from the students of education majors.

The investigation that underpins this article was performed based on the following analysis categories: (1) Curriculum: pedagogical practice and school structure where the collection of strategies, methods and techniques that characterize the teaching work and the pedagogical actions is involved. The school structure refers to the expressions of the students about the possible characteristics that the future education centers will have with regard to infrastructure and resources. (2) The teacher's and the student's profile: the first one is understood as the set of abilities, skills and attitudes (the professional profile) that the teacher should master in the future to be able to perform relevantly in his/her professional space. The student's profile refers to the set of competences, characteristics, interests and demands that the students will present in the future and that affect the educational processes. (3) The concept of family: is the set of beliefs that the students manifest with regard to the structure, the dynamics and the participation that the family of the future will have in the educational processes of their children. (4) The concept of community: is centered on the beliefs that the students express about the interaction spaces between the educational players and the influence that those spaces have in the educational process.

\section{MATERIAL AND METHODS}

The investigation was performed with the mixed overlapping design (Creswell \& Plano-Clark, 2007) where the quantitative data and the qualitative information merge for the study of the phenomenon. This included the application of a survey and the development of a 4-week forum of virtual reflection. Each technique is detailed below:

The survey: was applied to 911 persons, who constituted a sample of the student population of the licentiate degree of the majors of the School of Education Sciences (ECE-its acronym in Spanish) of the Universidad Estatal a Distancia de Costa Rica (the total population was of 3625 persons), and the work was done with a margin of error of $2.8 \%$. A questionnaire was used made up of three parts: the first referring to the socio-demographic data, the second consisting on a scale of valuation and the third, a sole 
open question about the teacher profile in the future. The scale is made up of 48 statements. For each one of the statements, the participants will express their opinion through the selection of one of the five points or categories, between complete agreement and complete disagreement.

The reflection virtual forum: was denominated "New scenarios of the teaching profession" and the students who were enrolled during the third quarter of 2013 in the subjects Administration for the development of curriculum (code 325) and Principles and methodology of research in education I (code 2095) were invited to participate. The forum was carried out over four weeks. The generating questions were proposed and it was moderated.

The processing of the data collected was performed through an analysis of descriptive statistics; central trend frequencies and measurements. The qualitative information was processed through categorization and the data obtained in the survey was triangulated with the information originating from the virtual forum. The 911 students who participated in the survey came from the different majors of the ECE, as can be appreciated in table 1. From that population, 79 students were selected with whom the virtual forum was held.

Table 1. Distribution of participants according to major of origin, 2013

\begin{tabular}{lrr}
\hline \multicolumn{1}{c}{ Major } & N & \multicolumn{2}{c}{$\%$} \\
\hline General Basic Education Cycles I and II & 385 & 42,3 \\
\hline Pre-school Education & 216 & 23,7 \\
\hline Licentiate degree in Teaching & 157 & 17,2 \\
\hline Special Education & 50 & 5,5 \\
\hline Education Computer Science & 45 & 4,9 \\
\hline Education Management & 40 & 4,4 \\
\hline Social Studies and Civic Education & 18 & 2,0 \\
\hline Total & 911 & 100,0 \\
\hline
\end{tabular}

\section{RESULTS}

In the participation in the virtual forum, most of the interventions, that is, 146, were oriented towards the condition of status quo, since they do not propose significant transformations regarding the conditions evaluated. However, on the contrary, there are 91 comments that do reflect ideas for change. These results are a constant in the data analysis, according to the ordering of the subjects that were set out for the participants, as can be viewed in Figure 1.

The comments that allude to changes in the scenarios are related, mostly, with the subjects of family and community. In the case of the subject on teacher and student, the comments that prevail are pointed towards the continuity of the status quo. In what refers to curriculum and pedagogical practice, one does not see any abrupt changes, but rather an inclination for the scenarios to maintain the trends revealed to this moment, or else, they refer to conditions that more than being desirable, are found embedded in the "should be" or are even found in the standard requirements of the traditional education system.

\subsection{Curriculum, pedagogic practice and school structure}

During the investigation, the participants, to answer the question of how they view the school of the future, do not transcend a traditional view, although they consider the technological advances and even virtual education, as an education model for the future. The perceptions of the participants regarding the school of the future do not advance towards setting forth substantive changes in the being and doing of schools, but rather they stop at the identification of means, without a deeper reflection about the educational organization, the contents, the practices and the pedagogic processes that characterize it.

Among the changes that the participants perceive for the school of the future are changes with regard to mandatory attendance to the education centers. Teaching is seen as in a distance model and the student will assume responsibility of his/her own learning. For example:

"The education institutions of the future 2033 will possibly be globalized $[\ldots]$ the teacher will no longer play the role he/she plays today [...] The schools [...] the student will work at his/ her own rhythm and in his/her own home" (Participant 17).

Another characteristic mentioned by the participants refers to the loss of hegemony of the written text and in physical format and the predominance of texts in digital format.

The participants of the study seem to focus on the transformation of the school in the use of digital and Internet technologies without delving deeper into aspects related with contents or strategies of how to incorporate those technologies into the learning processes.

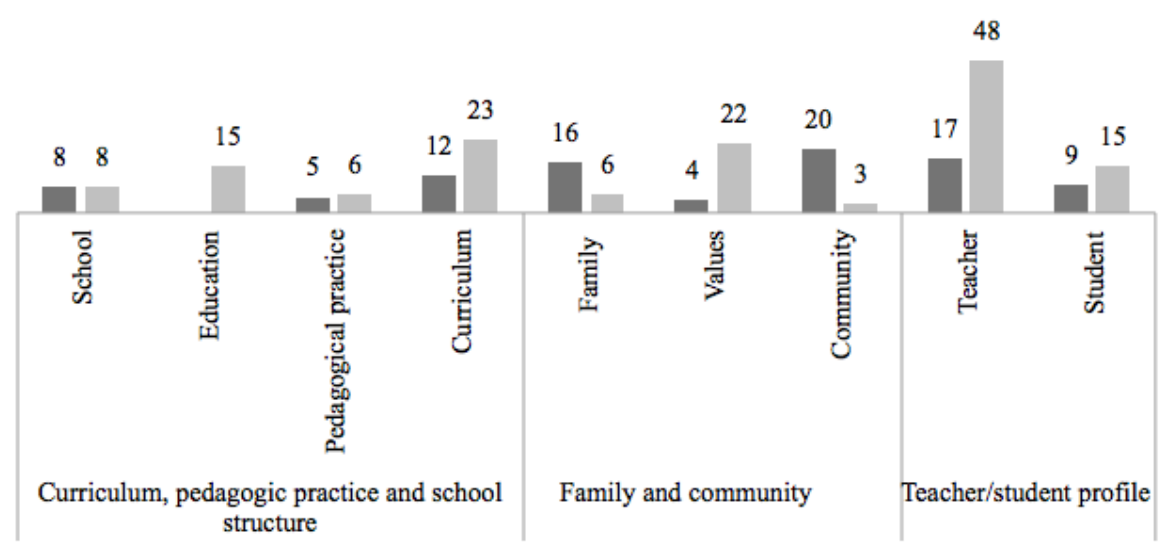

Figure 1. Classification of the comments offered by the participants in the virtual forum, according to subjects and orientation of the change alluded to Source: Author's own development based on the interventions of the participants in the virtual discussion forum. 
Another of the relevant aspects that the participants consider the school of the future should have, refers to the capacity to generate in the student body the interest for learning, in the words of one of the participants:

"One should count on the full commitment of the teachers, who currently should renew their practices and update themselves" (Participant 8).

In what refers to the curricular proposals through the interventions set forth by the participants, they show that they visualize that in the future, education will require flexible curricula and with regard to the pedagogical practice, the participants express the need for change in the learning strategies, as observed in the following narrative:

"The pedagogical practice has already changed, lectures are for listening, but the significant learning will have to adapt to that flexible and open curriculum, the interaction, simulation, coexistence of spaces for collaborative work may be more versatile, not as rigid as the classroom" (Participant 29).

The positions expressed by the participants in the forum correspond to the answers of the 911 surveyed persons where one notices a tendency of the teaching exercise towards a scenario of change with regard to contents, work- spaces and teaching methodology. It should be noted that $87.4 \%$ of the participants stated different degrees of agreement with regard to the statement: "I think that in the future the main function of the teacher will be to generate knowledge and plan educational processes, more than dictating a lecture class." The lecture class as the main resource for the exercise of teaching tends to weaken in the future proposed. $47.4 \%$ of the participants versus $26.9 \%$ believe that in the future this resource "will no longer have a reason to exist."

With regard to the changes related with the educational processes that are projected for the future proposed, $82 \%$ of the participants validate the idea that in the future there will be new alternative spaces instead of the traditional concept of the teaching exercise, in other words, the educational spaces will change and also the way the teaching processes are developed.

Traditionally, the school has been attributed the responsibility of creating, within its facilities, the experiential conditions that facilitate education with those values that society claims as priority for its wellbeing. The study inquired about the perception of the student body with regard to this function which has been socially conferred to the school and found that $52.7 \%$ of the participants, in different degrees of agreement, expressed that the school of the future will be oriented towards educating in obedience, order and respect for authority.

\subsection{Main competences for the teacher of the future}

The education professional must have a profile that includes both generic competences as well as specific competences to satisfy the demands and social needs that the new contexts lay out on education matters.

Although the concept of competence is recognized as multidimensional (Rangel, 2015; Rodríguez, Serreri, \& Del Cimmut, 2010) for this investigation, the model of Villa and Poblete (2008) was used, which offers the concept of competence as "the good performance in various and authentic contexts based on the integration and activation of knowledge, standards, techniques, procedures, abilities and skills, attitudes and values" (p. 24).

With regard to the general organization of the competences mentioned by the participants, it was found that most of them correspond to instrumental competences (42\%); in second place, the interpersonal competences $(35 \%)$; and in a third order, the set of systemic competences $(23 \%)$.
The category of cognitive competences was mentioned by 22 persons ( 15 were about critical thinking and 7 concerned analytical thinking). The remaining cognitive competences (systemic thinking, reflexive, logical, analogical, practical, creative and deliberative) were not mentioned. Due to the above, it seems that the students who participated in the study do not consider the relevance of the cognitive competences in the educational processes (Solano \& Campos, 2014).

With regard to the interpersonal competences, the participants in the study gave priority to the competences referred to the ethical sense, the resistance and adaptation to the environment and diversity and interculturality (Solano \& Campos, 2014).

\subsection{Characteristics of the students of the future}

The participants foresee changes in the role of the student. In the concrete case of the student-teacher interaction, $65.1 \%$ state different degrees of agreement with the statement "in the school of the future the interaction between the student and the teacher will change drastically."

The explosion of information, its ubiquitous access, the accelerated expansion of the digital technologies and their penetration into all the social contexts, will incontrovertibly influence this traditional relation. A new type of student is emerging: digital natives, net, millennium, whatever one wishes to call them, who will very possibly claim new ways of teacher-student interaction. In different degrees of agreement, the participants declare that the defining ability that will characterize the student of the future is learning. This is observed in $71.4 \%$ and in $87.6 \%$ of those surveyed who expressed that opinion.

The accustomed relation education-teaching is now presented as education-learning. The current and future learning demands are being forced by an accelerated development of science and technology and the obsolescence itself of knowledge.

The participants in the study do not provide enough information to create a profile of the student of the future, although some characteristics can be retrieved.

\section{Digital Consumers}

"I believe that it will be a highly technological population, full of concerns about what is novel and what is innovative, they will seek to have more and more access to the different means and technological devices" (Participant 30).

\section{Social Skills}

"Children will be very competent with regard to the use of technologies, they will have developed greater independence of thinking, they will be more active in the search for answers to situations they are presented with" (Participant 19).

\section{Polyglot}

"The competences that every student should have in the future will be a greater knowledge not only in one field but in several. They will no longer have to master one language, but rather three or four" (Participant 7).

\section{Discernment}

"They should learn to discern about the reliability and quality of the information" (Participant 18).

In summary, the student of the future will have greater emphasis on characteristics such as the mastery of social skills, creativity, multi-languages, autonomy and independent 
thinking. Similarly, for most of them, technological mastery, capacity of adaptation, learning to learn and competitiveness will be the most important aspects related with the students in the next decades.

\subsection{Concept of family and community}

In the discursive context of the participants, the family as understood in its traditional concept (nuclear family) fades away and a wide range of family structures emerge. The participants are concerned with the consequences that the changes in the family lead to and the contradictions that globalization and the explosion of social networks in cyberspace seem to be causing in the system of values that once safeguarded the family, as can be observed in the following fragments:

"While parents teach one thing at home, technologies teach another. Strong confrontations occur and will occur. For example, while the parents teach the importance of self-esteem and to respect ourselves first so that others may respect us, among young people on-line showing their bodies is being promoted as acceptable, almost like a form of prostitution, and anyone who does not do it is not following the standards of that community" (Participant 22).

This was verified with the opinions expressed by the participants in the survey where the vast majority, almost $76.1 \%$ states, in different degrees of agreement, believe that in the future the family models will be very different from the traditional concept.

The involvement of the family in the education processes is observed as an important concern for the students. The concern about whether the family in the future will lose leadership in the educational process of the children is expressed in the fact that almost half of them, $48.7 \%$ said they did not agree with the statement "I believe that in the future the family will lose leadership in the educational process of the children."

With regard to the actions of the family in the context of the school system, the participants evidence a somewhat optimistic perception regarding their role as protagonists in the educational processes of their descendants; in that sense, $67.3 \%$ submitted different levels of agreement with the statement that the family will have a greater participation in the educational processes of the children. Similarly, $49.3 \%$ of those surveyed indicated that in the future, the families will participate in the development of educational programs.

Based on the study performed, one can conclude that in what refers to the family and its involvement in the education scenarios and tasks, the participants perceive significant changes.

With regard to the concept of community, the students who participated in the investigation said that for the future, the community will also undergo relevant changes. That is, the old-fashioned community that built the collective identity will fade, animated by the information and communication technologies. The participants state certain concerns for this matter, since the community, upon losing its physical support (spaces where it is located), transfers to cyberspace, and with this in the new scenario, face to face interactions become digitalized.

\section{DISCUSSION}

In general terms, the participants tend to view a future with scenarios for education, which are very similar to the current ones. Despite the imperious need for transformation, the school, as a social institution, shows a reactive position with regard to the social requirements and demands and its change rhythm is one of the slowest in the system (Calatayud, 2008; Marina; 2015; Toffler, 2006), as can be appreciated in Figure 2. The slow advance of the school institution presumes the great risk of becoming "obsolete social instances or that come to serve purposes that are not those that gave origin to it, or that find it difficult to perform their function in the changing social circumstances" (Moreno, 2008, p. 16).

Some studies about the shaping of identity in the education professionals (Pereira, Lopes, \& Marta, 2015) point out the need for working on this point from their initial training processes in the institutions that training them, so that, as well as working on the competences identified by the participants of this study, it is necessary that the universities also reinforce the development of the professional identity.

With regard to education about the values of obedience and discipline that in the opinion of some participants the school should continue developing, one must ask if in the era of knowledge (Rodríguez, 2015), it is convenient for the school to assist in the shaping of these values.

It is relevant that the students identify the technological competences as one of the main types of knowledge that characterize the teacher of the future, since indeed that is a key competence in education (Ayala, 2011; Cabero, 2015; Cervera \& Lázaro, 2015; Ilomäki, Kantosalo, \& Lakkala, 2010; Leu, Kinzer, Coiro, \& Cammack, 2004; Pelagajar, 2015; Quesada \& Tejedor, 2016; Roblizo \& Cózar, 2015; Sancho \& Padilla, 2016; Teo, 2009).

The participants express in different degrees of agreement that the most defining ability of the student of the future will be learning. All these observations are related also with the position of the author Barbero (2000), who underlines the coexistence of different channels, additional to the school, through which knowledge circulates and is built.

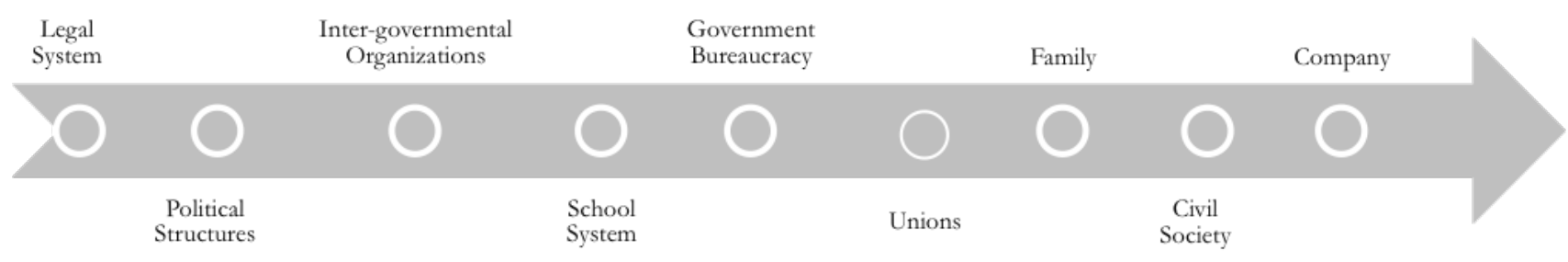

Figure 2. Social Structure Change Rhythms, according to Toffler, 2006. Source: Authors' own development based on the change rhythm model through Toeffler's highway analogy (2006) 
One of the subjects that the participants relate more with family has to do with the shaping of values. That is why they link values most importantly with the Costa Rican identity and family, conceived from a traditional perception. In both cases, the values claimed presumably originate from the myth of the "exceptional Costa Rican" (Molina, 2003).

The participants focus their attention on the aspirations and issues of the present that require attention, such as awakening the interest for learning, the loss of control of the parents, the absence of education policies in accordance with the new realities, the search for flexibility in the curricula, the increase of demands of the education players and the growing emergence of education proposals with an intensive use of ICTs.

With regard to the subject of family, the participants coincide that in the future its traditional conception will experience transcendental changes and will continue to migrate towards different typologies. This with the changing condition of the concept, the structure, composition and dynamics of the family system that several authors reiterate (Bolívar, 2006; Forsberg \& Nätkin, 2016; Polichroniadis, Oldfield, \& Holmes, 2011) and its relevance in the educational processes (Darling-Hammond, 2010; Unicef, 2007). In the same way, the students who participated in the study foresee changes in the concept of community mainly due to the delocalization and the emergence of virtual communities.

One of the matters that concerned the participants most alludes to the subject of values. Standing out amongst these is the trend to project towards the proposed future, values of a social character, typical of an industrial economic model based on the labor force, to others ostensibly founded on the information and the knowledge through which the society of the future is supposed to travel through. In the case of the ethical and moral values, the discussion of the participants tended to find ties around the Costa Rica identity and the family as a priority. In both cases, they appeal to the usual argument of a value crisis as an instrument to explain and justify those social behaviors that transgress the status quo.

With regard to the subject of fundamental competences for the teacher in the future, the participants in order of importance highlighted: the use of digital technologies, ethics, and orientation towards learning and interpersonal communication. It must be recognized that confronted with the profiles of the current society, this proposal of competence is quite accurate. Nevertheless, in this exercise the participants overlooked essential competences for access to information and knowledge in a homonymous era: cognitive and linguistic competences.

In regard to the characteristics of the student in the future, according to the manifestations of the participants, the distinctive element will be the capability for learning, autonomy and the intensive use of technologies.

One of the aspects most mentioned by the participants was the growing incorporation of technologies in the education processes. Although certainly, the overlapping of technologies is a strong trend in the education process, that alone is not a guarantee for the improvement of quality, but rather in some circumstances the incorporation of technologies may have a negative impact on the educational results (Levis, 2011; Teo, 2009).

\section{CONCLUSIONS}

As can be inferred from the data, the participants do not consider novel education processes but rather the glimpses of the education of the future refer, fundamentally, to initiatives or practices that are carried out today with lesser or greater efforts. The participants focus their attention on the aspirations and problems of the present that require attention, such as awakening the interest for learning, the loss of control of the parents, the absence of education policies in accordance with the new realities, the search for flexibility in the curricula, the increase of demands by the education players and education's dependence on ICTs.

Participants coincide in that the learning capability, autonomy and the intensive use of technologies will be the distinctive characteristic of the student of the future. In addition, they state that both the family as well as the communities will continue with the transformation that they are experiencing and this will inevitably influence the education processes.

According to the participants in this study, the fundamental competences of the teacher of the future will be: the use of digital technologies, ethics, orientation to learning and interpersonal communication. The cognitive and linguistic competences, despite their relevance, are not considered.

\section{REFERENCES}

Ayala, T. (2011). El aprendizaje en la era digital. Revista Electrónica Diálogos Educativos, 21(11), 3-20.

Baofu. P. (2011). The Future of post-human Education: A preface to a New Theory of Teaching and Learning. Cambridge: Cambridge International Science Publishing.

Barbero, J. M. (2002). Jóvenes: comunicación e identidad. Pensar Iberoamérica. Revista Digital de Cultura de la OEI, 0. Retrieved from http://www.oei.es/revistacultura/secc_03/secc_03_1/pdf/print.pdf

Bolívar, A. (2006). Familia y escuela: dos mundos llamados a trabajar en común. Revista de Educación, 339, 119-146.

Cabero, J. (2015). Reflexiones educativas sobre las tecnologías de la información y las comunicaciones (TIC). CER, 1, 19-27.

Calatayud, M. (2008). La escuela del futuro. Hacia nuevos escenarios. Madrid: Editorial CCS.

Cervera, M. G., \& Lázaro, J. (2015). Professional development in teacher digital competence and improving school quality from the teachers' perspective: a case study. Journal of New Approaches in Educational Research, 4(2), 115-131. doi:org/10.7821/naer.2015.7.123

Creswell, J. W., \& Plano-Clark, V. L. (2007). Designing and conducting mixed methods research. Thousand Oaks, CA: Sage Publications.

Darling-Hammond, L. (2010). Teacher Education and the American Future Journal of Teacher Education, 61(1-2), 35-47. doi:10.1177/0022487109348024

Forsberg, H., \& Nätkin, R. (2016). Families in the Future: Stories of Finnish Students. Journal of Comparative Family Studies, 47(1), $27-43$.

Freyman, R. (2011). Sed de futuro. Ciencia Ergo Sum, 17(3), 318-322.

Hargreaves, A., \& Lo, L. N. K. (2000). The paradoxical profession: Teaching at the turn of the century. Prospects, 30, 167. doi:10.1177/0022487109348024

Ilomäki, L., Kantosalo, A., \& Lakkala, M. (2010). What is digital competence. Linked project.

Leu, D. J., Kinzer, C. K., Coiro, J. L., \& Cammack, D. W. (2004). Toward a theory of new literacies emerging from the Internet and other information and communication technologies. Theoretical models and processes of reading, 5, 1570-1613.

Levis, D. (2011). Redes educativas 2.1 medios sociales, entornos colaborativos y procesos de enseñanza y aprendizaje. Revista de Universidad y Sociedad del Conocimiento, 8(1), 7-42. doi:10.7238/rusc.v8i1.965

Marina, J. (2015). Despertar al diplodocus una conspiración educativa para transformar la escuela y todo lo demás... Barcelona: Ariel.

MacBeath, J. (2012). Futuro of teaching profession. University of Cambridge. Retrieved from https://xa.yimg.com/kq/groups/3564013/942471036/name/Future Teaching_Prof_2012.pdf

Molina, I. (2003). Costarricense por dicha. Identidad nacional y cambio cultural en Costa Rica durante los siglos XIX y XX. San José, Costa Rica: Editograma.

Moreno, M. (2008). El estudiante ante la diversidad de situaciones en la era digital. Apertura, 8(8), 7-17.

Oficina Internacional de Educación. (2004). Escenarios para la educación del siglo XXI: síntesis de un diálogo inconcluso y preguntas para su continuidad. Revista Perspectivas, 34(2), 49-67.

Organización para la Cooperación y el Desarrollo Económico (2010). Habilidades y competencias del siglo XXI para los aprendices del nuevo milenio en los países del OCDE. Working Paper 21st Century Skills and Competencies for New Millennium Learners in OECD Countries) EDU Working paper no. 41). Retrieved from http://www.ite.educacion.es/

Pavlyuk, V.\& Ivanchyuk, H. (2016). Comparative Professional Pedagogy, 6(1), 3640. doi:10.1515/rpp-2016-0005 
Pelagajar, M. C. (2015). Educación inclusiva y TIC: análisis de actitudes en futuros docentes. Journal for Educators, Teachers and Trainer, 6(1), 275-289.

Pereira, F., Lopes, A., \& Marta, M. (2015). Being a teacher educator: professional identities and conceptions of professional education. Educational Research, 57(4), 451-469. doi:10.1080/00131881.2015.1078142

Polichroniadis, M., Oldfield, A., \& Holmes, J. (2011). Creating Change for Complex Children and Their Families: A Multi-disciplinary Approachi to Milti-family Work. London: Jessica Kingsley Publishers.

Quesada, A., \& Tejedor, S. (2016). Aplicaciones educativas de los videojuegos: el caso de World of Warcraft. Píxel-Bit. Revista de medios y Educación, 48, 187196. doi:10.12795/pixelbit.2016.i48.12

Rangel, A. (2015). Competencias docentes digitales: propuesta de un perfil. Píxel-Bit. Revista de medios y Educación, 46, 2171-7966.

Roblizo, M. \& Cózar, R. (2015). Usos y competencias en TIC en los futuros maestros de educación infantil y primaria: Hacia una alfabetizción tecnológica real para docentes. Píxel-Bit. Revista de Medios y Educación, 47, 23-39. doi:10.12795/ pixelbit.2015.i47.02

Rodríguez, M. L., Serreri, P., \& Del Cimmuto, A. (2010). Desarrollo de competencias: teoría y práctica. Balance, proyecto profesional y aprendizaje basado en el trabajo. Barcelona: Laertes Educación

Rodríguez, S. M. (2015). Redes de colaboración académica: una respuesta a los desafíos de la globalización y la sociedad del conocimiento. Sinéctica, 44 .

Sancho, J., \& Padilla, P. (2016). Promoting digital competence in secondary education: are schools there? Insights from a case study. New Approaches in Educational Research, 5(1), 57-63.

Solano, W., \& Campos, J. (2014). Hacia la construcción de un perfil para el docente del futuro. Revista Innovacioines Educativas, 85-107.

Sikula, J. (1989). The Future of the Teaching Profession. Teacher Education Quarterly, 16(2), 63-75.

Teo, T. (2009). Modelling Tecnology Acceptance in Education: a study pre-service teachers. Computer \& Education, 302-312.

Toffler, A., \& Toffler, H. (2006). La revolución de la riqueza. México: Debate.

UNICEF. (2007). Child Friendly School. School and Community. Retrieved from http://www.unicef.org/education/files/CFSManual_Ch04_052009.pdf

Villa, A., \& Poblete, M. (2008). Aprendizaje basado en competencias. Una propuesta para la evaluación de las competencias genéricas. Bilbao: Mensajero.

How to cite this article: Campos, J., \& Solano, W. (2017). The future of the teaching profession from the perspective of students with a Major in Education. Journal of New Approaches in Educational Research, 6(2), 87-92. doi: 10.7821/naer.2017.7.191 